\title{
ANALISIS PERSPEKTIF GLOBAL GURU PENGARUHNYA TERHADAP EFEKTIVITAS PEMBELAJARAN DI SMK NEGERI KOTA PADANGSIDIMPUAN
}

\author{
Oleh : \\ Hanafi $^{1}$, Armansyah Lubis ${ }^{2}$ \\ ${ }^{1,2}$ Institut Pendidikan Tapanuli Selatan \\ ${ }^{1}$ hanafi2568@gmail.com \\ 2armansyahlubis80@gmail.com
}

\begin{abstract}
Abstrak
Penelitian ini bertujuan untuk membangun suatu model hipotesis yang terdiri dari model struktural dan model pengukuran dalam bentuk diagram jalur yang berdasarkan justifikasi teori dari variable perspektif global guru dan efektivitas pembelajaran. Populasi dalam penelitiuan ini adalah seluruh guru SMK Negeri di Kota Padangsidimpuan yang telah tersertifikasi yaitu sejumlah 338 orang. Penarikan sampel dilakukan secara proporsional dsampling dengan jumlah 110.orang. Instrumen penelitian ini adalah kuesioner. Kuesioner digunakan untuk mengumpulkan data perspektif global guru dan efektivitas pembelajaran. Data yang diperoleh dianalisis dengan metode SEM. Dari hasil penelitian menunjukkan bahwa: (1) terdapat pengaruh positif persfektif global guru terhadap efektifitas pembelajaran sebesar 15,9\%; Hasil-hasil penelitian ini dapat mengkorfirmasi kesimpulan hasil penelitian sebelumnya
\end{abstract}

Kata Kunci : Perpektif global, efektifitas pembelajaran

\section{PENDAHULUAN}

Ketidaksiapan akan dampak globalisasi tentu bisa ditangggulangi dengan penguasaan ilmu pengetahuan dan teknologi, yang tentunya harus diawali dengan kesadaran dan wawasan perspektif global yang dimilki generasi bangsa. Dengan perspektif yang semakin mengglobal kita dapat memahami dunia dan seisinya, sehingga menumbuhkan kesadaran bahwa dunia yang begitu kompleks dan luas itu dapat menjadi sempit dan sederhana. Sehingga kita perlu untuk mengkaji lebih dalam pentingnya berwawasan perspektif global yang erat kaitannya dengan: landasan pendukung kesadaran dan wawasan global yang diperlukan, bidang kekuatan globalisasi, peningkatan daya saing dalam globalisasi, kesadaran peserta didik untuk berperspektif global, pengembangan wawasan global melalui pendidikan, pengantisipasian arus globalisasi, sampai konsep inovasi untuk peningkatan wawasan global.

Sekolah Menengah Kejuruan (SMK) sebagai sekolah yang berorientasi pada lulusan yang siap kerja, harus bisa mencetak sumber daya manusia yang unggul memiliki kemampuan hard skills sekaligus soft skills yang memadai yang dibutuhkan oleh dunia kerja saat ini. Permasalahn yang krusial saat ini bahwa pendidikan SMK saat ini masih cenderung berorientasi pada hard skills saja, tentu saja sudah tidak relevan dengan tuntutan dunia usaha, apalagi di era global saat ini. Permasalahan rendahnya kemampuan hard skills sekaligus soft skills siswa ini begitu kompleks. Jika permasalahan tersebut dibiarkan begitu saja, maka lulusan sekolah kejuruan tidak akan diterima dalam lapangan pekerjaan yang pada akhirnya akan meningkatkan angka pengangguran.
Permasalahan yang sering muncul adalah kurang efektifnya pembelajaran yang disebabkan oleh kurang kesiapan dan profesinalisme guru sebagai salah satu komponen utama dalam proses pembelajaran. Guru yang dianggap berkompeten dan relevan dengan kebutuhan SMK bukan hanya berkualifikasi saja tetapi juga berkomitmen untuk selalu menjadikan pendidikan sebagai pendidikan sepanjang hayat, sehingga proses perbaikan diri dan pengembangan wawasan akan terus menerus terjadi dan menerapkannya dalam kehidupan demi masa depan peserta didik. Berdasarkan data di lapangan menujukkan bahwa kelayakan guru dalam mengajar masih meragukan, dan masih minimnya jumlah guru yang memenuhi kualifikasi standar pada pendidikan kejuruan. Sejumlah penelitian membuktikan bahwa guru yang profesional merupakan salah satu indikator penting dari sekolah berkualitas. Guru yang profesional akan sangat membantu proses pencapaian visi misi sekolah. Mengingat strategisnya peran yang dimiliki oleh seorang guru, usaha-usaha untuk mengenali dan mengembangkan profesionalisme guru menjadi sangat penting untuk dilakukan.

Pemerintah Daerah Kota Padangsidimpuan telah berupaya meningkatkan profesionalisme guru di antaranya meningkatkan kualifikasi dan persyaratan jenjang pendidikan yang lebih tinggi, khususnya SMK Negeri se-Kota Padangsidimpuan, yaitu setiap guru yang mengajar pada SMK Negeri wajib memiliki kualifikasi minimal Strata I (Sarjana) dan seluruh guru diupayakan menjadi guru tersertifikasi. Disamping itu dinas pendidikan kota Padangsidimpuan berupaya mengaktifkan musawarah guru mata pelajaran (MGMP) namun ternyata hasil dari 
program Pemerintah Daerah Kota Padangsidimpuan tersebut belum memuaskan.

Penelitian ini penting dilakukan karena hasil penelitian ini dapat dijadikan dasar untuk pengambilan kebijakan dalam menumbuhkan profesionalisme dan wawasan global guru melalui efektivitas pembelajaran. Diantara upaya untuk meningkatkan efektivitas pembelajaran ini dapat dilakukan dengan meningkatkan perspektif global guru. Penelitian ini diharapkan mampu menjawab masalah rendahnya kualitas guru dan ini akan menjadi salah satu alternatif jawaban terhadap tuntutan peningkatan prefesionalisme guru dan efektivitas pembelajaran secara berkesinambungan yang terus harus dilakukan sesuai perkembangan ilmu pengetahuan dan tuntutan globalisasi.

Efektivitas merujuk pada kemampuan untuk memiliki tujuan yang tepat atau mencapai tujuan yang telah ditetapkan. Menururt Abbott J (1994), Learning .. that reflective activity which enables the learner to draw upon previous experience to understand and evaluate the present, so as to shape future action and formulate new knowledge" Belajar ... adalah kegiatan reflektif yang memungkinkan siswa untuk memanfaatkan pengalaman sebelumnya untuk memahami dan mengevaluasi masa sekarang serta merumuskan pengetahuan baru untuk membentuk tindakan di masa depan.

Pembelajar yang efektif merupakan pembelajaran yang aktif dan strategis, terampil dalam kerjasama, dialog dan menciptakan pengetahuan dengan orang lain, mampu mengembangkan tujuan dan rencana dan melakukan evaluasi. Efektivitas juga berhubungan dengan masalah bagaimana pencapaian tujuan atau hasil yang diperoleh, kegunaan atau manfaat dari hasil yang diperoleh, tingkat daya fungsi unsur atau komponen, serta masalah tingkat kepuasaan pengguna. Pembelajaran dinilai efektif ketika aktivitas belajar siswa meningkat. Efektivitas pembelajaran mengacu pada proses dan pada hasil, yang dilihat dari keterlibatan siswa dalam proses pembelajaran dan kompetensi yang dicapai siswa dari hasil belajar.

Perspektif global merupakan pandangan yang timbul dari kesadaran bahwa dalam kehidupan ini segala sesuatu selalu berkaitan dengan isu global. Orang sudah tidak memungkinkan lagi bisa mengisolasi diri dari pengaruh global. Manusia merupakan bagian dari pergerakan dunia, oleh karena itu harus memperhatikan kepentingan sesama warga dunia. Akibat adanya perkembangan teknologi maka segala aspek kehidupan manusia semakin transfaransi dan mengglobal, demikian juga dengan pendidikan.

Perspektif global diartikan sebagai suatu cara pandang dan cara berpikir terhadap suatu masalah, kejadian atau kegiatan dari suatu kepentingan global, yaitu dari sisi kepentingan dunia atau internasional. Oleh karena itu sikap dan perbuatan kita diarahkan untuk kepentingan global. Dalam berpikir, seseorang harus berpikir secara global, dan bertindak dapat secara lokal. Dalam hal ini kita diingatkan bahwa apa yang kita lakukan akan mempengaruhi dunia secara global. Menurut Hanvey (1976) dalam bukunya yang sangat terkenal "An Attainable Global Perspective" menyebutkan 5 dimensi dari perspektif global sebagai berikut.a) Perspective conciousness b) State of planet awareness c) State of planet awareness d). Systemic awareness e) Options for participation.

Perspektif global sangat penting bagi pendidik, mengingat bahwa kita sedang memasuki era globalisasi dan keterbukaan. Tanpa memahami dunia ini, mungkin kita tersesat oleh arus globalisasi yang begitu deras. Agar kita mampu memanfaatkan dunia ini bagi kesejahteraan manusia maka kita harus memahami dunia. Dengan demikian cara pandang kita yang mungkin sempit selama ini harus berubah menjadi cara pandang yang luas dan global. Artinya segala sesuatu peristiwa, dan masalah harus dipandang dari sudut kepentingan global

Guru SMK merupakan salah satu komponen utama dalam proses pendidikan. Oleh sebab itu, berusaha memahami tantangan dan masalah yang akan dihadapi oleh guru SMK pada masa depan merupakan upaya yang baik untuk mengembangkan profesionalisme guru SMK di era globalisasi. Sehubungan dengan presfektip global seorang guru SMK harus berperan; a).Memberikan bekal pengetahuan kepada siswa tentang pentingnya pengetahuan global dalam memahami masalah-masalah dunia, b).Meningkatkan kesadaran dan wawasan anak didik sebagai landasan dalam melakukan tindakan yang berdampak global, dan c) Memberikan contoh dan teladan dalam aktifitas sehari-hari, yang mempunyai pengaruh terhadap masalah global.

Tujuan umum pengetahuan tentang perspektif global adalah selain untuk menambah wawasan juga untuk menghindarkan diri dari cara berpikir sempit, terkotak oleh batas-batas subyektif, primordial (lokalitas) seperti perbedaan warna kulit, ras, nasionalisme yang sempit, dsb. Dengan demikian pentingnya (urgensi) wawasan perspektif global dalam pengelolaan pendidikan ialah sebagai langkah upaya dalam peningkatan mutu pendidikan nasional. Hal ini dikarenakan seperti yang telah dituliskan sebelumnya, dengan wawasan perspektif global kita dapat menghindarkan diri dari cara berpikir sempit dan terkotak-kotak oleh batas subyektif sehingga pemikiran kita lebih berkembang. Penelitian Bassey Enya dan Josephine Dasel (2014) dengan judul Teacher Education And Global Standard For Effective Teachinglearning Process In Public Secondary Schools In Calabar Municipality, Cross River State, Nigeria. Dari hasil data yang dianalisis dari hipotesis, sudah jelas 
bahwa, standar pendidikan global memiliki hubungan yang positif dengan proses pembelajaran. Hasil ini sejalan dengan cara untuk menunjukkan bahwa, variabel pendidikan lainnya bersifat konstan atau setara. Guru dari institusi pendidikan guru akan membantu negara-Nigeria untuk mencapai standar pendidikan yang lebih tinggi dan akan menjadi proses belajar-mengajar yang efektif. Guru yang telah mengukuti pelatihan guru akan menerapkan teknik yang mereka pelajari dalam proses pemdelajaran. Keadaan ini membuat siswa akan mengerti apa yang telah diajarkan pada mereka. Dengan pelatihan kinerja akademis mereka akan menjadi tinggi, dan meningkatkan prestasi akademis siswa secara keseluruhan. Dalam penelitian ini juga diperoleh hasil bahwa guru yang tersertifikasi memliki kompetensi lebih dibandingkan guru yang tidak tersertifikasi.

Penelitian ini penting dilakukan karena hasil penelitian ini dapat dijadikan dasar untuk pengambilan kebijakan dalam menumbuhkan profesionalisme dan wawasan global guru melalui efektivitas pembelajaran. Diantara upaya untuk meningkatkan efektivitas pembelajaran ini dapat dilakukan dengan meningkatkan perspektif global guru. Penelitian ini diharapkan mampu menjawab masalah rendahnya kualitas guru dan ini akan menjadi salah satu alternatif jawaban terhadap tuntutan peningkatan prefesionalisme guru dan efektivitas pembelajaran secara berkesinambungan yang terus harus dilakukan sesuai perkembangan ilmu pengetahuan dan tuntutan globalisasi.

\section{METODE PENELITIAN}

\section{Jenis dan Teampat Penelitian}

Sesuai dengan permasalahan dan tujuan penelitian yang ingin dicapai, penelitian ini menggunakan metode Kuantitatif dengan jenis penelitian Ex post facto. Penelitian ini dilaksanakan di SMK Negeri se Kota Padangsidimpuan Tahun 2019

Teknik Analisis Data

Analisis data dalam penelitian ini mengunanakan analisis deskriftip, uji asumsi serta analisis statistic menggunakan analisis Structural Equation Modeling (SEM) berdasarkan atas beberapa alasan sebagai berikut: pertama, penelitian ini ingin menguji model secara struktural, menguji pengaruh variabel eksogen yaitu Persfektif Global Guru terhadap variabel endogen yaitu Efektivitas Pembelajaran Secara terperinci. Pengujian dilakukan terhadap kesesuaian model melalui goodness of fit dengan indeks-indeks tersebut maka dapat dibuat tabel untuk melihat kreteria yang ditentukan.

\section{HASIL DAN PEMBAHASAN}

Model struktural diajukan untuk menguji hipotesis penelitian. Model struktural menggambarkan hubungan 2 variabel laten, yaitu: persfektif global guru dan efektivitas pembelajaran.
Variabel laten persfektif global guru oleh 5 variable manifes yaitu PG1, PG2, PG3,PG4 dan PG5. Variabel laten efektivitas pembelajaran direpresentasikan oleh tujuh variabel manifes EP1, EP2, EP3, EP4, EP5, EP6, dan EP7. Model tersebut dapat digambarkan sebagaimana Gambar berikut ini:

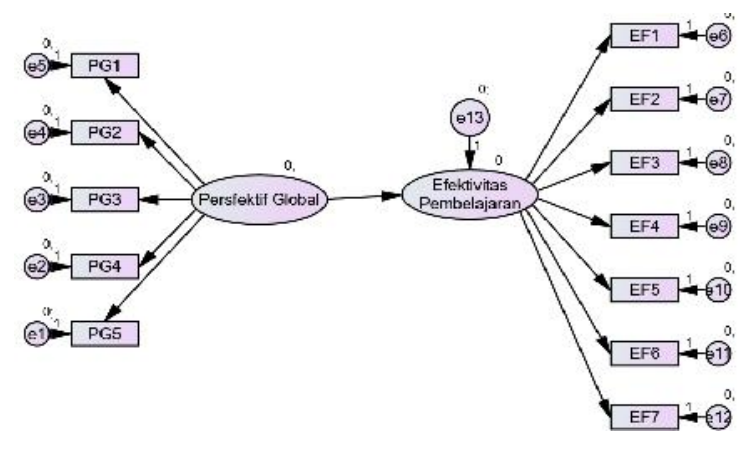

Gambar 1. Model Struktural yang Menggambarkan Keterkaitan Antar Variabel untuk Menguji Hipotesis Penelitian

Dari Gambar dapat dijelaskan bahwa parameter yang bersifat fixed (tidak diestimasi) ada 14, yaitu: 0 error weights, 0 regression weights dan 2 residual weights. Parameter yang diestimasi sebanyak 12, yaitu 4 regression weights dan 8 variances. Banyaknya parameter unik (distinct parameters) yang diestimasi sebanyak 12 sedangkan banyaknya unsur sample covariance matrix adalah $(8 \times 9) / 2=36$, sehingga model ini mempunyai derajat kebebasan (degree of freedom) sebanyak $36-14=22$. Model diatas dapat diidentifikasi dengan status overidentified. Dengan parameter yang diestimasi sebanyak 14 buah, model diatas mempunyai derajat kebebasan $36-12$ $=22$. Nilai Chi Square $(\chi 2)$ dari model diatas adalah 30,223 dengan level probabilitas 0,078 ( $\geq$ 0,05). Nilai ini menunjukkan bahwa H0 yang menyatakan bahwa tidak ada perbedaan antara sample covariance matrix $(\boldsymbol{\Sigma})$ dengan implied covariance matrix ( $\Sigma(\theta)$ ) tidak dapat ditolak, sehingga model ini secara keseluruhan adalah fit dan dapat diterima. Indeks kesesuaian model selengkapnya dapat dilihat pada tabel berikut ini:

Tabel 1.Nilai Keluaran Uji Kecocokan Model untuk Model Struktural

\begin{tabular}{lccc}
\hline $\begin{array}{l}\text { Goodness of } \\
\text { index }\end{array}$ & $\begin{array}{l}\text { Cut-of } \\
\text { value }\end{array}$ & Output & Keterangan \\
\hline $\begin{array}{l}\text { Significaned } \\
\text { Probability }\end{array}$ & $\geq 0.05$ & 0,078 & Fit \\
GFI & $\geq 0.90$ & 0,876 & Marginal Fit \\
AGFI & $\geq 0.90$ & 0,956 & Fit \\
NFI & $\geq 0.90$ & 0,985 & Fit \\
RFI & $\geq 0.90$ & 0,900 & Fit \\
IFI & $\geq 0.90$ & 0.987 & Fit \\
TLI & $\geq 0.90$ & 0,997 & Fit \\
CFI & $\geq 0.90$ & 0,987 & Fit \\
RMSEA & $\leq 0.08$ & 0,986 & Fit \\
CMIN/DF & $\leq 2.00$ & 1,448 & Fit
\end{tabular}


Dari Tabel 1, terlihat bahwa hampir keseluruhan uji kelayakan model untuk Model Struktural dalam kondisi cocok (fit) kecuali AGFI yang berada pada posisi Marginal Fit. Sementara itu, output Regression Weight dari AMOS 22 untuk Model Struktural dapat dilihat dalam tabel berikut

Tabel 2. Estimasi Regression Weights dari Model Struktural

\begin{tabular}{|c|c|c|c|c|c|c|}
\hline & & & Estimate & S.E & C.R & $\mathrm{P}$ \\
\hline Efektivitas & & Perspektif & & ,070 & 2,232 & ,020 \\
\hline \multirow[t]{2}{*}{ Pembelajaran } & $<---$ & Global &, 160 & & & \\
\hline & & Perspektif & 1,000 & & & \\
\hline \multirow[t]{2}{*}{ PG5 } & $<--$ & Global & & & & \\
\hline & & Perspektif & 1,000 & & & \\
\hline \multirow[t]{2}{*}{ PG4 } & $<--$ & Global & & & & \\
\hline & & Perspektif & 1,000 & & & \\
\hline \multirow[t]{2}{*}{ PG3 } & $<--$ & Global & & & & \\
\hline & & Perspektif & 1,000 & & & \\
\hline \multirow[t]{2}{*}{ PG2 } & $<--$ & Global & & & & \\
\hline & & Efektivitas & 1,000 & & & \\
\hline \multirow[t]{2}{*}{ PG1 } & $<--$ & Pembelajaran & & & & \\
\hline & & Efektivitas & 1,000 & & & \\
\hline \multirow[t]{2}{*}{ EF1 } & $<--$ & Pembelajaran & & & & \\
\hline & & Efektivitas & 1,000 & & & \\
\hline \multirow[t]{2}{*}{ EF2 } & $<---$ & Pembelajaran & & & & \\
\hline & & Efektivitas & 1,000 & & & \\
\hline \multirow[t]{2}{*}{ EF3 } & $<--$ & Pembelajaran & & & & \\
\hline & & Efektivitas & 1,000 & & & \\
\hline \multirow[t]{2}{*}{ EF4 } & $<--$ & Pembelajaran & & & & \\
\hline & & Efektivitas & 1,000 & & & \\
\hline \multirow[t]{2}{*}{ EF5 } & $<--$ & Pembelajaran & & & & \\
\hline & & Efektivitas & 1,000 & & & \\
\hline \multirow[t]{2}{*}{ EF6 } & $<--$ & Pembelajaran & & & & \\
\hline & & Efektivitas & 1,000 & & & \\
\hline EF7 & $<--$ & Pembelajaran & & & & \\
\hline
\end{tabular}

Dari Tabel 2, terlihat bahwa keseluruhan tingkat signifikansi hubungan antar konstruk laten yang dihipotesiskan adalah signifikan, yang ditandai dengan nilai probabilitas (P) yang lebih kecil dari 0,05 . Hipotesis $1(\mathrm{H} 1)$ yang menyatakan bahwa "Terdapat pengaruh positif perspektif global guru terhadap efektivitas pembelajaran di SMK Negeri di Kota Padangsidimpuan" tidak dapat ditolak secara signifikan, pada level 0,05, dengan nilai kritis (critical ratio) sebesar 2,321. Pada kolom estimasi juga dapat dijelaskan bahwa ketika perspektif global naik 1 tingkat, maka efektivitas pembelajaran mengalami kenaikan 0,159. Kesimpulannya, H1 diterima.

Penelitian ini menemukan adanya pengaruh positif variabel perspektif global guru terhadap efektivitas pembelajaran secara signifikan dan tidak dapat ditolak. Temuan ini dapat mengkonfirmasi temuan penelitian yang dilakukan oleh:

Penelitian Bassey Enya dan Josephine Dasel (2014) dengan judul Teacher Education And Global Standard For Effective Teachinglearning Process In Public Secondary Schools In Calabar Municipality, Cross River State, Nigeria. Dari hasil data yang dianalisis dari hipotesis, sudah jelas bahwa, standar pendidikan global memiliki hubungan yang positif dengan proses pembelajaran. Hasil ini sejalan dengan cara untuk menunjukkan bahwa, variabel pendidikan lainnya bersifat konstan atau setara. Guru dari institusi pendidikan guru akan membantu negara-Nigeria untuk mencapai standar pendidikan yang lebih tinggi dan akan menjadi proses belajar-mengajar yang efektif. Guru yang telah mengukuti pelatihan guru akan menerapkan teknik yang mereka pelajari dalam proses pemdelajaran. Keadaan ini membuat siswa akan mengerti apa yang telah diajarkan pada mereka. Dengan pelatihan kinerja akademis mereka akan menjadi tinggi, dan meningkatkan prestasi akademis siswa secara keseluruhan. Dalam penelitian ini juga diperoleh hasil bahwa guru yang tersertifikasi memliki kompetensi lebih dibandingkan guru yang tidak tersertifikasi.

Temuan penting lainnya adalah penelitian Leah dkk,(2013) dengan judul Perspective Global perspective in curricula and deep approaches to learning: Examining faculty practices for engagement. Penelitian ini menghasilkan hubungan yang signifikan dan positif antara Perspektif Global dengan pembelajaran Reflektif \& Integratif, dan Higher-Order Learning. Penelitian ini juga menghasilkan kurikulum global harus mengandung tingkat refleksi yang tinggi, pertimbangan berbagai sudut pandang, dan pemikiran mendalam tentang isu-isu kompleks. Persfek global mencerminkan pandangan global dan holistik tentang pembelajaran dan pengembangan siswa. Untuk itu peran lingkungan sekolah sangat penting dalam mendorong perkembangan siswa secara holistik. Ini mengukur bagaimana seorang siswa berpikir, memandang dirinya sebagai orang dengan warisan budaya, dan berhubungan dengan orang lain dari budaya, latar belakang dan nilai lain. Penelitian ini membandingkan perspektif global siswa keperawatan dengan norma nasional siswa dari berbagai disiplin ilmu. Kekuatan budaya, ekonomi, politik, dan sosial yang berkembang di masyarakat global sangat mempengaruhi kesehatan lokal dan global siswa pada umumnya. Dalam studi saat ini, menggunakan Global Perspective Inventory (GPI) dengan tujuan untuk mengukur pertumbuhan dan perkembangan seseorang sebagai konsekuensi dari pengalaman hidup.. GPI telah digunakan secara luas dengansiswa. Ini dibangun untuk mengukur bagaimana siswa mendapatkan wawasan tentang dunia di sekitar mereka, dan bagaimana wawasan ini mempengaruhi persepsi diri dan hubungan interpersonal mereka.

Kesimpulannya, temuan penelitian ini menunjukkan adanya kebutuhan akan pembelajaran yang meningkatkan kompetensi intrapersonal siswa dengan beragam orang lain. Pendekatan perspektif global untuk pembelajaran antar budaya adalah area yang perlu dikembangkan lebih lanjut dan pilihan yang berbeda harus diperiksa. Kompetensi global siswa akan sangat mempengaruhi perkembangan karir mereka di masa depan.

\section{KESIMPULAN}

Simpulan dari penelitian ini adalah perspektif global guru mempunyai pengaruh positif terhadap efektivitas pembel;ajaran di SMK Negeri Kota Padangsidimpuan 


\section{SARAN}

Saran yang disampaikan adalah (1) disarankank kepada kepala sekolah sebagai pengambil kebijakan untuk terus meningkatkan kompetensi guru melalui berbagai pendidikan dan pelatihan khususnya dibidang persfektip global, (2) disarankan kepada para guru untuk terus meningkatkan wawasan global demi peningkatan efektivitas pembelajaran

\section{DAFTAR PUSTAKA}

Abbott J.1994. Learning makes sense : re-creating education for a changing future, Letchworth: Education

Bassey Enya dan Josephine Dasel.2014. dengan judul Teacher Education And Global Standard For Effective Teachinglearning Process In Public Secondary Schools In Calabar Municipality, Cross River State, Nigeria

Delors, J. et al.1996. Learning the Treasure Within, Education for the 21th Century. New York : UNESCO.

Hanvey,Robert,G.1976.AnAttainableGlobalPerspe ctive.ttp://ebookbrowse.com/hanvey-anattainable-global-perspective-pdfd379707707

Macbeath \& Peter, 2005 Effects of Teachers' Effectiveness on Students' Academic Performance in Public Secondary Schools; Delta State - Nigeria 